\title{
Role of CRP (C- Reactive Protein) in clinical outcome in patient of PPROM
}

\author{
Shaidul Islam Borah, Gokul Chandra Das, Laxmi Deori \\ Correspondence: Dr. Shaidul Islam Borah, Associate Professor, Department of Obstetrics \\ and Gynaecology, Jorhat Medical College and Hospital, Jorhat, Assam; Email - \\ drshaidulislamborah3@gmail.com
}

Distributed under Creative Commons Attribution-Share Alike 4.0 International.

\begin{abstract}
Objective: To evaluate the role of CRP in clinical outcome in patient of PPROM. Methodology: A prospective study was done on 90 cases with PPROM and raised CRP $(>9 \mathrm{mg} / \mathrm{l})$ and 90 cases of control group with PPROM and normal CRP $(<9 \mathrm{mg} / \mathrm{l})$. All mothers and babies were observed from the time of admission to the time of discharge. Results: The incidence of chorioamnionitis was seen to be higher in the cases with raised CRP. The socioeconomic status, parity were found to have an important role in patients developing chorioamnionitis. The sensitivity of the test (raised CRP) in causing clinical chorioamnionitis is more than $90 \%$ and specificity in 50\%. Odds ratio is 12.5 i.e cases (raised CRP) have 12.5 times more chances of having clinical chorioamnionitis than those of controls (normal CRP). Conclusion: In cases of PPROM, raised CRP is a predictor of clinical chorioamnionitis.
\end{abstract}

Keywords: CRP, PPROM, chorioamnionitis, socioeconomic status.

The normal development, structural integrity and function of the fetal membranes are essential for the normal progress of pregnancy, process of labour and outcome of pregnancy. One of the most important functions of the membrane is to remain intact until the onset of labour at term. Without intervention, their spontaneous rupture usually occurs near the end of first stage of labour. However in about $10 \%$ of pregnancies, fetal membranes fails to maintain their structural integrity and ruptures either before term or at term, but before onset of labour and of these cases, about $98 \%$ lands up in labour within 48 hours. If the rupture of the membranes occurs after 28 weeks but before 37 weeks of gestation it is termed as PPROM (Preterm Premature Rupture of Membrane) and when it ruptures after onset of labour it is called PROM (Premature Rupture of Membrane) ${ }^{1}$. The incidence of PPROM is variable between $2-4.5 \%$ of all deliveries ${ }^{2}$. It is responsible for $30 \%$ of preterm deliveries and contributes around $10 \%$ of perinatal mortality.

Maternal complications of PPROM are chorioamnionitis, unfavourable cervix, cord prolapse, cord compression, dysfunctional labour, increased incidence of caesarean section, PPH, subinvolution, puerperal sepsis, post partum haemorrhage, endometritis. Fetal complications include increased

Received: $14^{\text {th }}$ December 2016. Accepted: $15^{\text {th }}$ April 2017.

Borah SI, Das GC, Deori L. Role of CRP (C- Reactive Protein) in clinical outcome in patient of PPROM. The New Indian Journal of OBGYN. 2017; 4(1):17-21 
incidence of prematurity, growth retardation, intrauterine infection, fetal infection, fetal distress, IUFD, hyaline membrane disease, intraventricular haemorrhage, postural deformity, neonatal sepsis - all of which leads to increased morbidity and mortality of the newborn ${ }^{3-7}$.

Early detection of infection would allow preterm birth to be expedited. The use of laboratory marker would help to distinguish women at risk from those whose pregnancy can be safely prolonged to facilitate timely management to avoid mortality and morbidity. Those that might be earlier used in routine care are CRP levels, WBC count, ESR and bacterial analysis of vaginal samples.

CRP is an acute phase protein synthesized in the liver during infection. It is a sensitive marker of inflammation that remains stable in serum. Production of CRP is stimulated by release of pro inflammatory cytokines including interleukin1, IL-6, INF-alpha. Although sometimes referred to as acute phase reactant, CRP accompanies both acute and chronic inflammatory disorder. Elevated concentration of CRP is seen both in the peripheral circulation and in the amniotic fluid in patients with intrauterine infection ${ }^{8,9}$. CRP is being used in different parts of the world as early predictor of chorioamnionitis. The aim of the study was to evaluate the role of CRP in clinical outcome in patient of PPROM.

\section{Methodology}

The study on the role of raised CRP $(>9 \mathrm{mg} / \mathrm{l})$ in clinical outcome in patient of PPROM in 90 cases between 28-36 weeks of gestation with equal number of control groups ( 90 cases of PPROM with normal CRP levels, $<9 \mathrm{mg} / \mathrm{l}$ ) was conducted at Department of Obstetrics and Gynaecology, Gauhati Medical College and Hospital within the period of May 2012 to April 2013. Pregnant women with singleton pregnancy, cephalic presentation, between 28-36 weeks with PPROM were included in this study. A patient is clinically diagnosed to be having chorioamnionitis if temperature $>100$ degree $\mathrm{F}$, Tachycardia $>100 /$ min $\left(1^{\text {st }}\right.$ inclusion criteria) with or without uterine tenderness and foul smelling discharge per vaginum $\left(2^{\text {nd }}\right.$ inclusion criteria, subjective). Exclusion criterias were multiple pregnancies, uterine anomalies, myoma uterus, antepartum haemorrhage, chronic renal failure, class 2 and class 4 cardiac diseases, gestational diabetes, fetal weight $<1 \mathrm{~kg}$ and $>2.5 \mathrm{~kg}$, post caesarean pregnancy and pregnancy with fetal anomalies.

The data were collected in structured proforma. After admission, detailed workup including history, general physical examination, abdomen and pelvic examination and relevant/specific investigations were noted. Data were analyzed through relevant statistical tools. This study was initiated after taking permission from institutional ethic committee.

\section{Results}

The total number of deliveries during the study period was 15111 (May 2012- April 2013) of which $800(5 \%)$ cases were PPROM. In our study with 90 cases of positive CRP status (CRP level > 9mg/l), 20

Table 1: Analysis of PPROM cases with CRP status with clinical course according to the socioeconomic status

\begin{tabular}{|c|c|c|c|c|}
\hline \multirow[b]{2}{*}{$\begin{array}{l}\text { Socio- } \\
\text { econo- } \\
\text { mic } \\
\text { status }\end{array}$} & \multicolumn{2}{|c|}{ Study group } & \multicolumn{2}{|c|}{ Control group } \\
\hline & $\begin{array}{l}\text { Cases } \\
\text { with } \\
\text { raised } \\
\mathrm{CRP}>9 \\
\mathrm{mg} / \mathrm{dl}\end{array}$ & $\begin{array}{l}\text { Chorioamn } \\
\text { ionitis } \\
\text { cases, } \\
\mathrm{No}(\%)\end{array}$ & $\begin{array}{l}\text { Cases } \\
\text { with } \\
\text { raised } \\
\mathrm{CRP}<9 \\
\mathrm{mg} / \mathrm{dl}\end{array}$ & $\begin{array}{l}\text { Chorioam } \\
\text { nionitis } \\
\text { cases, No } \\
(\%)\end{array}$ \\
\hline $\begin{array}{l}\text { Upper } \\
\text { class }\end{array}$ & 3 & 0 & 3 & 0 \\
\hline $\begin{array}{l}\text { Middle } \\
\text { class }\end{array}$ & 7 & $1(14.2 \%)$ & 7 & 0 \\
\hline $\begin{array}{l}\text { Lower } \\
\text { class }\end{array}$ & 80 & $19(23.7 \%)$ & 80 & $2(2.5 \%)$ \\
\hline
\end{tabular}

cases shows sign and symptoms of chorioamnionitis $(22 \%)$. Out of 90 control group (CRP $<9 \mathrm{mg} / \mathrm{l})$, two shows sign and symptoms of chorioamnionitis (2\%). This findings is statistically significant $(\mathrm{p}=0.001)$.

In our study lower class represents maximum cases with PPROM with raised CRP, 80 cases, out of which $23.7 \%$ shows sign and symptoms of chorioamnionitis. Control group shows $2.5 \%$ chorioamnionitis in lower socio-economic group. Most of the cases coming 
GMCH were from lower socio-economic group and multipara category. In this study 20 cases of PPROM

Table 2: Analysis of PPROM cases with CRP status with clinical course according to booked or unbooked cases, parity, duration of PPROM, gestational age, baby weight.

\begin{tabular}{|c|c|c|c|c|c|c|}
\hline \multirow{2}{*}{ Categories } & & \multicolumn{2}{|c|}{ Study group } & \multicolumn{2}{|c|}{ Control group } & \multirow[b]{2}{*}{$\begin{array}{l}P \\
\text { value }\end{array}$} \\
\hline & & $\begin{array}{l}\text { CRP>9 } \\
\mathrm{mg} / \mathrm{l}\end{array}$ & $\begin{array}{l}\text { Chorioam- } \\
\text { nionitis } \\
\text { cases, } \\
\text { No }(\%)\end{array}$ & $\begin{array}{l}\text { CRP< } \\
9 \mathrm{mg} / \mathrm{l}\end{array}$ & $\begin{array}{l}\text { Chorioam } \\
\text { - nionitis } \\
\text { cases, } \\
\text { No }(\%)\end{array}$ & \\
\hline Booked / & Booked & 5 & 0 & 5 & 0 & 0.05 \\
\hline Unbooked & Unbooked & 85 & $20(23.5 \%)$ & 85 & $2(2.3 \%)$ & \\
\hline Parity & $\begin{array}{l}\text { Primi } \\
\text { Multi }\end{array}$ & $\begin{array}{l}20 \\
70\end{array}$ & $\begin{array}{l}1(5 \%) \\
19(27 \%)\end{array}$ & $\begin{array}{l}20 \\
70\end{array}$ & $\begin{array}{l}0 \\
2(2.8 \%)\end{array}$ & 0.1 \\
\hline Duration of & $<12$ hrs & 10 & 0 & 10 & 0 & 0.015 \\
\hline PPROM (in & $13-24 \mathrm{hrs}$ & 20 & 0 & 20 & 0 & \\
\hline hours) & $>24 \mathrm{hrs}$ & 60 & $20(33 \%)$ & 60 & $2(3 \%)$ & \\
\hline Gestational & $28-30 \mathrm{wks}$ & 20 & $5(25 \%)$ & 20 & 0 & \\
\hline age & 31-34 wks & 40 & $10(25 \%)$ & 40 & $2(5 \%)$ & \\
\hline & $35-36 \mathrm{wks}$ & 30 & $5(16.6 \%)$ & 30 & 0 & \\
\hline Baby weight & $1-1.5 \mathrm{Kg}$ & 20 & $5(25 \%)$ & 20 & 0 & \\
\hline in $\mathrm{Kg}$ & $1.6-2 \mathrm{Kg}$ & 40 & $10(25 \%)$ & 40 & $2(5 \%)$ & \\
\hline & $2.1-2.5 \mathrm{Kg}$ & 30 & $5(16.6 \%)$ & 30 & 0 & \\
\hline
\end{tabular}

(>24 hour draining) with raised CRP shows sign and symptoms of chorioamnionitis $(33 \%)$ and this is statistically significant $\quad(\mathrm{p}=0.015)$. PPROM cases with raised CRP were $22 \%$ in $28-30$ weeks $(1-1.5 \mathrm{~kg})$, out of which $25 \%$ shows sign and symptoms of chorioamnionitis, $44 \%$ in 31-34 weeks $(1.5-2 \mathrm{~kg})$ out of $25 \%$ shows sign and symptoms of chorioamnionitis, $33 \%$ in $35-36$ weeks $(2-2.5 \mathrm{~kg})$ out of which $16.6 \%$ shows sign and symptoms of chorioamnionitis. Control low literacy rate.

In this study, 95\% of PPROM cases with raised CRP were unbooked, out of which $23.5 \%$ shows sign and symptoms of chorioamnionitis. Multipara represent $77 \%$ of the PPROM cases with raised CRP, out of which $27 \%$ shows sign and symptom of chorioamnionitis. In primipara it is $22 \%$ out of which group shows $2 \%$ chorioamnionitis in 31-34 weeks category. The incidence of chorioamnionitis was high when baby weight was less than $2 \mathrm{~kg}$ (1-2kg).

The mode of delivery in accordance to parity and fetal weight did not show any statistical significance. Most of the patients give consent for vaginal delivery, so were put in expectant management and were delivered in meantime.

In CRP raised mother (study Table 3: Analysis of PPROM cas
course and perinatal morbidity

\begin{tabular}{|c|c|c|c|}
\hline \multirow[t]{2}{*}{ Causes } & \multicolumn{2}{|c|}{ Study group } & \multirow{2}{*}{$\begin{array}{l}\text { Control } \\
\text { group } \\
\text { CRP<9mg/l } \\
\text { cases in } \\
\text { Number }\end{array}$} \\
\hline & $\begin{array}{l}\text { CRP>9mg/l } \\
\text { cases in } \\
\text { Number }\end{array}$ & $\begin{array}{l}\text { Chorioamnionitis } \\
\text { cases in Number }\end{array}$ & \\
\hline Hyperbilirubinaemia & 65 & 20 & 15 \\
\hline Sepsis & 60 & 20 & 5 \\
\hline RDS & 5 & 5 & 10 \\
\hline Birth asphyxia & 1 & 1 & - \\
\hline
\end{tabular}

5\% shows sign and symptom of chorioamnionitis. In control group shows $2.8 \%$ cases of chorioamnionitis in mortality is $22 \%$. The mortality is more in $28-32$ weeks gestation with $\mathrm{EFW}<2 \mathrm{~kg}$. More than $50 \%$ perinatal 
mortality is due to RDS.

In control groups perinatal mortality is $4 \%$. Sepsis also accounted for $10 \%$ perinatal mortality.

In our study the sensitivity and specificity in predicting chorioamnionitis in cases of PPROM by

Table 4: Contingency table of counts based on the diagnostic test and gold standard

\begin{tabular}{llll}
\hline $\begin{array}{l}\text { Diagnostic } \\
\text { test }\end{array}$ & $\begin{array}{l}\text { Non-chorioamnionitis } \\
\text { Cases }\end{array}$ & $\begin{array}{l}\text { Chorioamnionitis } \\
\text { Cases }\end{array}$ & Total \\
\hline CRP $<9 \mathrm{mg} / 1$ & 88 & 2 & 90 \\
CRP $>9 \mathrm{mg} / 1$ & 70 & 20 & 90 \\
\hline & Estimated value & $\begin{array}{l}\text { Lower limit(95\% } \\
\text { confidence level) }\end{array}$ & $\begin{array}{l}\text { Upper limit(95\% } \\
\text { confidence level) }\end{array}$ \\
\hline Prevalence & 0.122 & 0.07 & 0.16 \\
Sensitivity & 0.9 & 0.69 & 0.98 \\
Specificity & 0.5 & 0.42 & 0.57 \\
Odds ratio & & & 12.5
\end{tabular}

symptoms of chorioamnionitis, $33 \%$ in $35-36$ weeks (2$2.5 \mathrm{~kg}$ ), out of which $16.6 \%$ showed signs and symptoms of chorioamnionitis.

It has been seen that raised CRP concentration in PPROM cases is the most accurate infectious marker for prediction of early onset sepsis in routine use with a sensitivity $>90 \% \quad$ (Thomas Poposaki et al) ${ }^{13}$. Our study support this, as CRP cases without chorioamnionitis shows early onset sepsis in $86 \%$ of babies delivered.

In our study, perinatal mortality is $22 \%$, of which $45 \%$ is due to RDS, of which mortality is more in $28-32$
CRP was found to be $90 \%$ (high prediction for positive cases) and 50\% respectively.

\section{Discussion}

The incidence of PPROM in one year was found to be 5\% from May 2012-April 2013 and it was comparable to other hospitals of India, Swati et al (2000) showed $7.7 \%{ }^{10}$, Anjana Devi et al (1980) showed 5\% incidence. Out of 90 CRP positive cases, $22 \%$ had chorioamnionitis in study group. Ramsey et al. 2005 shows prevalence of $13 \%$ for clinical chorioamnionitis ${ }^{11}$. In the study group, lower socio economic class represents maximum cases with PPROM with raised CRP (88\%), out of which $23.7 \%$ showed signs and symptoms of chorioamnionitis.

In study group, multipara represented $77 \%$ of the PPROM cases with raised CRP, out of which $27 \%$ showed signs and symptoms of chorioamnionitis. Multiparity is a risk factor for PPROM due to long standing infection, previous trauma to cervix, patulous os. Distribution pattern is comparable to study by Sanyal rural medical college WB ${ }^{12}$. In this study, PPROM cases with raised CRP were $22 \%$ in $28-30$ weeks $(1-1.5 \mathrm{~kg})$,out of which $25 \%$ shows signs and symptoms of chorioamnionitis, $45 \%$ in $31-34$ weeks $(1.5-2 \mathrm{~kg})$, out of which $25 \%$ showed signs and weeks with weight $<2 \mathrm{~kg}$. This is comparable to study by Cox and colleague 52\% due to RDS ${ }^{14}$. The high incidence of maternal and neonatal infection may be a consequence of decreased anti-bacterial activity in the amniotic fluid which is low in early pregnancy and increases with gestational age. Another factor is the limited ability of the preterm infant to fight infection. Perinantal morbidity and mortality decreases as the birth weight increases.

Post partum complications were seen to be less, which could be because of the higher standard antibiotic coverage. No maternal mortality was recorded. The proportion of clinical chorioamnionitis cases in raised CRP cases was $22 \%$, which was significantly higher than those of controls. In our study, Odds ratio is 12.5 i.e cases (raised CRP) have 12.5 times more chances of having clinical chorioamnionitis than those of controls (normal CRP). In this study, the sensitivity of the test (raised CRP) in causing clinical chorioamnionitis is more than $90 \%$ and specificity in $50 \%$.Our study is comparable to Hawry llyshyn et al ${ }^{15}$, 1983 study which shown sensitivity of $100 \%$ \& specificity of $62 \%$.

\section{Conclusion}

From this study we can conclude that detection of maternal CRP in cases of PPROM at admission is the 
most sensitive marker (with sensitivity more than 90\%) for early prediction of clinical chorioamnionitis. It is also a sensitive marker for prediction of preterm delivery in PPROM and is also a sensitive marker for prediction of early onset neonatal infection. In cases of PPROM, raised CRP is a predictor of clinical chorioamnionitis.

\section{Conflict of interest: None. Disclaimer: Nil.}

\section{References}

1.Parry S, Strauss JF. Premature Rupture of The Fetal Membranes. New England Journal of Medicine. 1998; 338(10): 663-70.

2.Mercer BM. Preterm Premature Rupture of the Membranes. Obstetrics and Gynecology. 2003; 101(1):178-93.

3.Liu J, Feng ZC, Wu J. The incidence rate of premature rupture of membranes and its influence on fetal-neonatal health: a report from mainland China. J Trop Pediatr. 2010; 56: 36-42. [PubMed]

4.Wu J, Liu J, Feng Z, Huang J, Wu G. Influence of premature rupture of membranes on neonatal health. Zhonghua Er Ke Za Zhi Chin J Pediatr. 2009; 47: 452-56. [PubMed]

5.Velemínský M, Sák P. Management of pregnancy with premature rupture of membranes (PROM). Available from: medportal.ge/eml/publichealth/2006/n2/11.

6.ACOG Committee on Practice Bulletins-Obstetrics. ACOG Practice Bulletin No. 80: premature rupture of membranes. Clinical management guidelines for obstetrician-gynecologists. Obstet Gynecol. 2007; 109: 1007-19. [PubMed]

7.El-Messidi A, Cameron A. Diagnosis of premature rupture of membranes: inspiration from the past and insights for the future. J Obstet Gynaecol Can. 2010; 32: 561-69. [PubMed]

8.Nielsen FR, Bek KM, Rasmussen PE, Qvist I, Tobiassen M. C-reactive protein during normal pregnancy. Eur J Obstet Gynecol Reprod Biol. 1990; 35:
23-7. http://dx.doi.org/10.1016/0028-2243(90)90138-Q.

[PubMed]

9.Ghezzi F, Franchi M, Raio L, Di Naro E, Bossi G, D Eril GV, Bolis P. Elevated amniotic fluid C-reactive protein at the time of genetic amniocentesis is a marker for preterm delivery. Am J Obstet Gynecol. 2002; 186(2): 268-73.

10.Pandey S, Dave A, Bandi S. Maternal and fetal outcome in case of PPROM. Journal obstetrics and gynaecology of India. 2000; 50: 63.

11.Ramsey PS, Lieman JM. Chorioamnionitis increases neonatal morbidity in pregnancies complicated by PPROM. 2005; 192: 1162-6.

12.Sanyal MK, Mukherjee TN. Premature rupture of membranes an assessment from a rural medical college of West Bengal. J Obstet Gynaecol India. 1990; 40(5): 6238.

13.Popowski T, Goffinet F, Maillard F, Schmitz T, Leroy S, Kayem G. Maternal markers for detecting early-onset neonatal infection and chorioamnionitis in cases of premature rupture of membranes at or after 34 weeks of gestation: a two-center prospective study. BMC Pregnancy Childbirth. 2011; 11: 26. [PubMed]

14.Cox SM, Leveno KJ. Intentional delivery versus expectant management with preterm ruptured membranes at 30-34 weeks' gestation. Obstet Gynecol. 1995; 86: 875-79. [PubMed]

15.Hawrylyshyn P, Bernstein P, Millgan JE, Soldin S, Pollard A, Papsin FR. Premature rupture of membranes: the role of CRP in prediction of chorioamnionitis. Am J Obstet Gynecol. 1983; 147(3): 240-6. [PubMed]

\footnotetext{
Shaidul Islam Borah ${ }^{1}$, Gokul Chandra Das ${ }^{2}$, Laxmi Deori $^{3}$

${ }^{1}$ Associate Professor, Department of Obstetrics and Gynaecology, Jorhat Medical College, Jorhat, Assam, India; ${ }^{2}$ Professor, Department of Obstetrics and Gynaecology, Gauhati Medical College, Guwahati, Assam, India; ${ }^{3}$ Medial Officer, Naharani FRU, Assam.
} 